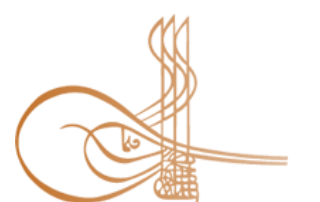

www.turkishstudies.net/economy
Turkish Studies - Economics, Finance, Politics

eISSN: $2667-5625$

Research Article / Araștırma Makalesi

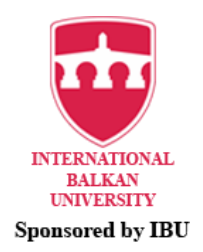

Sponsored by IBU

\title{
COVID-19 Pandemi Süreci ve Çalışma Hayatında Normalleşme Dönemi: Tapu ve Kadastro Genel Müdürlüğü Çalışanları Üzerine Bir Araştırma
}

\author{
COVID-19 Pandemic Process and Normalization Period in Working Life: A Research on the \\ Employees of the General Directorate of Land Registry and Cadastre
}

\author{
Betül Y1lmaz ${ }^{*}$ Yasin Y1lmaz ${ }^{* *}$
}

\begin{abstract}
The COVID-19 virus, which has been declared a pandemic by the World Health Organization, has affected the world in all areas. Although COVID-19 virus first showed its negative effects in the field of health, this situation also affected countries economically. Although the first COVID-19 case was seen in Turkey on March 11, 2020 the Turkish Government took a number of measures long before the appearance of cases. The number and quality of the measures taken in parallel with the increase in cases have also increased. Although the effects of the COVID-19 pandemic on the first day continue, each country has started to implement its own state policies in order to get through this process in the healthiest way with the new normalization steps dated June 1, 2020. With the COVID-19 pandemic process and the new normalization, Turkey has started to implement the regulations for the current working life in a controlled manner on behalf of the revival of economic and social life. In this context, four different loan packages were announced by the Ministry of Treasury and Finance for the revival of the economy. Public employees have continued to work actively since the first day of the COVID-19 pandemic. This situation raises the possibility to encounter the risk of the virus. The aim of this study is to measure the attitudes of public employees towards the pandemic during the COVID19 pandemic process and normalization period. The sample of the study consists of 2859 personnel affiliated to the central and provincial organization of the General Directorate of Land Registry and Cadastre. In the study, the questionnaire form was prepared on the web and the surveys were filled online. The questionnaire form was applied between the dates of 2nd-14th July 2020. The data gathered was approved by the Social and Humanities Ethics Committee of Bandırma Onyedi Eylül University, dated 26.06.2020 and numbered 4585.
\end{abstract}

\footnotetext{
* Dr. Öğr. Üyesi, Bandırma Onyedi Eylül Üniversitesi, İktisadi ve İdari Bilimler Fakültesi, Çalışma Ekonomisi ve Endüstri İlişkileri Bölümü

Asst. Prof. Dr, Bandirma Onyedi Eylul University, Faculty of Economics and Administrative Sciences, Department of Labour Economics and Industrial Relations

ORCID 0000-0002-3532-6479

bsolmaz@bandirma.edu.tr

** Dr. Öğr. Üyesi, Bandırma Onyedi Eylül Üniversitesi, İktisadi ve İdari Bilimler Fakültesi, Çalışma Ekonomisi ve Endüstri İlişkileri Bölümü

Asst. Prof. Dr, Bandirma Onyedi Eylul University, Faculty of Economics and Administrative Sciences, Department of Labour Economics and Industrial Relations

ORCID 0000-0002-4046-6580

yasinyilmaz@bandirma.edu.tr

Cite as/ Atıf: Yılmaz, B. \& Yılmaz Y. (2020). COVID-19 pandemi süreci ve çalışma hayatında normalleşme dönemi:

Tapu ve Kadastro Genel Müdürlüğü çalışanları üzerine bir araştırma. Turkish Studies - Economy, 15(3), 1715-1733. https://dx.doi.org/10.47644/TurkishStudies.45814

Received/Geliş: 14 August/Ağustos 2020

Accepted/Kabul: 20 September/Eylül 2020

Copyright C INTAC LTD, Turkey

Checked by plagiarism software

Published/Yayın: 25 September/Eylül 2020

CC BY-NC 4.0
} 
Descriptive statistics and factor analysis were used to evaluate the data. The result of the reliability analysis of the study is $86,9 \%$. According to the result of research; The "attitude scale of public employees' towards the pandemic" which was previously determined the consist of 2 factors, has evolved in to 3 factors with this study and has reached its final form.

Structured Abstract: The COVID-19 virus, which first appeared in Wuhan, China, has spread all over the world and has been declared a pandemic by the World Health Organization. Turkey has taken the necessary measures before the COVID-19 case was seen and the measures taken with the first case on 11 March 2020 have been gradually tightened. These measures and precaution have also been put into practice in working life. With the normalization period of 1 June 2020, the measures and precaution taken during the COVID-19 pandemic process have been reorganized and the working life has rectified to the new normal. During the pandemic and the period of normalization, public employees continued to work for the continuation of Public Service.

The aim of this study is to measure the attitudes of the employees of the General Directorate of Land Registry and Cadastre during the COVID-19 pandemic process and the normalization period due to the active work of public employees. During the COVID-19 pandemic process and normalization period, the personnel of the General Directorate of Land Registry and Cadastre are in communication with the citizens in the institution where they work. With the increase in citizens coming to the institution within the framework of the economic package announced during the normalization period, the workloads of employees also increased, and this increased the likelihood of employees being exposed to the COVID-19 virus. This makes study important for the selected sample. In the literature survey, there are not many studies on how public employees are affected by the pandemic process and what their attitude towards the pandemic is.

In this study the target population of the research consists of all public personnel connected to the General Directorate of Land Registry and Cadastre in Turkey. Today, the General Directorate of Land Registry and Cadastre is one of the oldest and most established institutions in the Turkish state system. It was first established in the Turkish state in 1847 under the name of Defterhane-i Amire Kalemi. Following the establishment of the Republic of Turkey, the General Directorate of Land Registry was established in 1924. The cadastral unit was added to the structure of this organization in 1925 by Law No. 658. The current structure of the General Directorate of Land Registry and Cadastre is determined by law No. 2997 dated 29 May 1936 and the organization is affiliated to the Ministry of Finance. The General Directorate of Land Registry and Cadastre was connected to many ministries until 08 July 2011 and finally continues its activities as an institution affiliated to the Ministry of Environment and Urban Planning (TKGM, 2020a).

The structure of General Directorate of Land Registry and Cadastre, which has 19254 personnel in total, consists of the Central and Provincial Organization. The Central Organization, which has 1184 personnel, consists of 12 Head of Departments, Legal Consultancy Department and Directorate for Revolving Fund Management. Staff in this unit are General Director, Deputy Director General, Head of Departments, Land Registry and Cadastre Expert, departmental manager, Engineer, Technical Staff, Computer Operator, Civil Servant, and Employees. The Provincial Organization consists of 24 Regional Directorates with 1359 personnel, 81 Cadastral Directorates with 5027 personnel and 973 Land Registry Directorates with 11684 personnel, which has the most personnel bar in the institution. Staff in this unit are Regional Director, Land Registry Director, Cadastre Director, Assistant Director of Land Registry, Technical Personnel, Computer Operator (TKGM, 2020 b). The random sampling method was used as the sample of the study considering the terms of accessibility. The survey form was delivered to all 19254 personnel of the General Directorate of Land Registry and Cadastre in Turkey via the internet through the General Directorate of Land Registry and Cadastre. In total 2859 personnel took part in the research as volunteers. In the study, the "attitude scale of public employees' towards the pandemic" developed by Yilmaz (2020) was used. The scale consists of 20 items in total in 5 Likert type and 2 factors were determined as individual attitude in the pandemic process and organizational attitude in the pandemic process. Reliability analysis of the scale is $97.4 \%$. In this study, the questions "attitude scale of public employees' towards the pandemic" were not changed and the demographic questions were increased to 13 items and the questionnaire was finalized with a total of 33 questions. The answers to the scale questions are in the form of $5 \mathrm{~s}$ of Likert ("I absolutely agree, I agree, I am ambivalent, I disagree, I absolutely disagree"). SPSS (Statistical Package for Social Sciences for Windows) package programs were used to evaluate the data obtained in the study. Descriptive statistics and factor analysis were used to evaluate the data. Reliability analysis of the scale is $86.9 \%$.

Turkish Studies - Economy, 15(3) 
According to the research results participants stated that their workload increased due to the housing loan included in the loan support package and that citizens visiting their offices to buy or sell houses posed a risk for them. Also, a new factor was added to the 2 factors developed with the "attitude scale of public employees' towards the pandemic" used in this study and the scale became final consisting of 3 factors in total. During the pandemic process, the scale consisting of individual attitude and organizational attitude has a new form with the 3 factor "work attitude" together with the result that occurs with the normalization period.

Questions in Factor 1:"I find the necessary precautions for the pandemic sufficient in the institution I work for". "I think that my working environment is healthy and reliable during the pandemic process". "I think my institution has been adequately disinfected". "I think the employees of the institution follow the social distance rules.". "I think my colleagues take the necessary precautions about health and safety". "I think that necessary information about COVID-19 has been supplied in the institution I work for (posters, information letters)". "I received training from my institution during the pandemic process".

Questions in Factor 2: "I'm worried about virus infection when I come to work every day". "I am afraid of infecting my family when I go home after work". "I think the citizen who come to the workplace pose a risk for us". "As the pandemic continues, I do not find it appropriate to return to normal working order". "In the pandemic process, even though I am healthy, I always feel like I have COVID-19 symptoms when I come to work". "I think that appropriate jobs in the institution should be turned into a way of working remotely". "Psychological support programs should be implemented in our institution after pandemic".

Questions in Factor 3: "Pandemic process affected my work motivation quite badly". "My performance decreased during the pandemic process". "My private life and work life have become unbalanced in the pandemic process". "My sleep quality deteriorated during the pandemic process". "I constantly follow the news on the internet/social media and it always negatively affects my thoughts that the COVID-19 pandemic will end". "Employees having administrative leave increased my workload more". In this study, with the results of factor analysis, the "attitude scale of public employees' towards the pandemic" was formed and each factor was named according to this study. Factor 1 was named as "Organizational Attitude in Pandemic". Factor 2 was named as "Individual Attitude in Pandemic", and Factor 3 was named as "Working Attitude in Pandemic".

With the normalization period of June 1, 2020, the measures and precaution taken during the COVID19 pandemic process were rearranged and work life returned to a new normal. During the COVID-19 pandemic and normalization period, civil servants continued to work for the continuation of the public service. This increased the likelihood of employees being exposed to the COVID-19 virus. This brought up the issue of what the employees' attitude towards the pandemic is. With this study, it has been revealed that it is necessary to investigate the attitude of public employees towards the pandemic. It is possible to say that a healthier and more efficient pandemic process is important not only for the employees, but also for the individuals the employees is responsible for. It is also important to evaluate the effects of the pandemic on employees during the pandemic process and normalization period and to provide the necessary psychological support for this. It is hoped that the results of this study will serve as an example for future studies.

Keywords: COVID-19, Pandemic, Normalization Period, General Directorate of Land Registry and Cadastre, Public Employees.

Öz: Dünya Sağlık Örgütü tarafından pandemi olarak ilan edilen COVID-19 virüsü dünyayı her alanda etkisi altına almıştır. COVID-19 virüsü ilk olarak sağlık alanında olumsuz etkilerini gösterse de bu durum ülkeleri ekonomik olarak da etkilemiştir. Türkiye'de ilk vaka 11 Mart 2020 tarihinde görülmesine rağmen Türk Hükümeti vakaların görülmesinden çok daha önce bir takım tedbirler almıştır. Vaka artışlarına paralel alınan tedbirlerin sayısı ve niteliği de artmıştır. COVID-19 pandemisinin ilk günkü etkileri devam etse de 1 Haziran 2020 tarihli yeni normalleşme adımları ile birlikte bu süreci en sağlıklı şekilde atlatabilmek için her ülke kendi devlet politikalarını uygulamaya başlamıştır. Türkiye, COVID-19 pandemi süreci ve yeni normalleşme ile birlikte ekonomik ve sosyal hayatın canlanması adına kontrollü bir şekilde mevcut çalışma hayatına yönelik düzenlemeleri uygulamaya başlamıştır. Bu bağlamda ekonominin canlanması için Hazine ve Maliye Bakanlığı tarafından dört ayrı kredi paketi açıklanmıştır. COVID-19 pandemisinin başladığı ilk günden günümüze kamu çalışanları aktif olarak çalışmalarına devam etmektedir. Bu durum, onların, virüs riski ile karşı karşıya kalma olasılığını da yükseltmektedir. Bu çalışmanın amacı; COVID-19 pandemi süreci ve normalleşme döneminde,

www.turkishstudies.net/economy 
kamu çalışanlarının pandemi karşısındaki tutumlarının ölçülmesidir. Araştırmanın örneklemi, Tapu ve Kadastro Genel Müdürlüğü merkez ve taşra teşkilatına bağlı 2859 personelden oluşmaktadır. Çalışmada anket formu web ortamında düzenlenmiş ve anketler online olarak doldurulmuştur. Hazırlanan anket formu 02-14 Temmuz 2020 tarihleri arasında uygulanmış ve çalışma verileri Bandırma Onyedi Eylül Üniversitesi Sosyal ve Beşeri Bilimler Etik Kurulu'nun 26.06.2020 kayıt tarih ve 4585 sayısı ile onaylanmıştır.

Verilerin değerlendirilmesinde tanımlayıcı istatistikler ve faktör analizi kullanılmıştır. Çalışmanın güvenilirlik analizi sonucu \% 86,9'dur. Araştırma sonucuna göre; daha önce 2 faktörden oluştuğu belirlenen "Kamu çalışanlarının pandemi karşısındaki tutum ölçeği”’ bu çalışma ile 3 faktöre evrilerek son halini almıştır.

Anahtar Kelimeler: COVID-19, Pandemi, Normalleşme Dönemi, Tapu ve Kadastro Genel Müdürlüğü, Kamu Çalışanları

\section{Giriş}

Salgın hastalıkların insanlığın toprağı işlemeye başlaması ile birlikte ortaya çıktığını söylemek mümkündür. Toprağın işlenmesi, tarım alanlarının genişlemesi ile birlikte doğada yaşayan fare, sivrisinek, kene, pire gibi canlıların insanlarla olan teması da kolaylaşmıştır. Bu temasla birlikte hayvanların taşıdığı tifüs, veba, tularemi ve sıtma gibi hastalıkları da ortaya çıkarmıştır (Yelboğa \&Aslan, 2020: 44). Bu hastalıklar, uluslararası sınırları aşarak tüm dünyaya yayılan enfeksiyon hastalıkları olması nedeniyle pandemi olarak tanımlanmıştır. Geçmişten günümüze kadar insanlık tarihi "ç̧içek hastalığı, veba, dang virüsü, AIDS, grip, şiddetli akut solunum sendromu (SARS), Batı Nil hastalı̆̆ ve tüberküloz" dâhil olmak üzere birçok pandemiyle karşılaşmıştır (Özkoçak, Koç, Gültekin, 2020: 1186). Günümüzde en son 2019 tarihinde Çin'in Wuhan kentinde ortaya çıkan ve kısa sürede tüm dünyaya yayılan COVID-19 virüsü 11 Mart 2020 tarihinde Dünya Sağlık örgütü tarafından pandemi olarak ilan edilmiştir (Zeybekoğlu Akbaş \& Dursun, 2020: 79).

Salgınlar, başta sağlık olmak üzere ekonomik, sosyal ve kültürel alanlarda da negatif etkiye sahiptir. Son yüzyılın en zor süreçlerinden birine neden olan COVID-19 pandemisinin yıkıcı etkisi kendini özellikle ekonomi alanında daha çok hissettirmiştir. 2 Mart 2020 tarihli OECD Ara Dönem Ekonomik Görünüm Raporu'nda finansal krizlerden bu yana COVID-19'un küresel ekonomi için büyük bir tehlike oluşturduğunu ifade etmiştir (OECD, 2020). Başlangıçta Asya ülkelerinde daha çok üretimde yaşanan aksaklıklar sonrasında dünya genelinde tedarik zincirlerinde de görülmüştür. Özellikle havacılık, lojistik, turizm ve konaklama alanlarında ciddi zorluklarla karşı karşıya kalınmıştır (Üstün \& Özçiftçi, 2020: 148). Küresel piyasaları olumsuz olarak etkileyen COVID-19 pandemisi Türkiye ekonomisi için de daraltıcı bir etki oluşturmuştur. Pandemi süreci ile birlikte getirilen seyahat kısıtlamaları, çeşitli kültürel, spor, sanatsal faaliyetlere ara verilmesi, turizmin durma noktasına gelmesi ülke ekonomisini olumsuz yönde etkilemiştir (Soylu Bayram, 2020: 183). Birçok sektörün COVID-19 pandemisi nedeniyle olumsuz yönde etkilenmesi işgücü piyasasında oluşacak emek arz ve talebinde de etkili olmuştur (Kara, 2020: 271). Devletin koruma kapsamı içinde yer alan kamu çalışanları için bu durum söz konusu değildir. COVID-19 pandemi sürecinde kamu hizmetinin devamı için kamu çalışanları bu dönemde aktif olarak çalışmaya devam etmiştir. $\mathrm{Bu}$ çalışmanın amacı pandemi süreci ve normalleşme döneminde çalışmaya devam eden kamu çalışanlarının pandemi karşısındaki tutumlarının değerlendirilmesidir. Çalışmada, ilk olarak Türkiye'de COVID-19 pandemi süreci ve normalleşme dönemi ile ilgi genel bilgiler verilmiş daha sonra pandemi süreci ve normalleşme dönemi ile çalışma hayatında alınan önlemler ve kamu çalışanlarına yönelik düzenlemelere yer verilmiştir. $\mathrm{Bu}$ kapsamda araştırmanın örneklemini oluşturan Tapu ve Kadastro Genel Müdürlüğü merkez ve taşra teşkilatına bağlı 2859 personelle yapılan anket sonuçları değerlendirilmiştir. 


\section{Türkiye'de COVID-19 Pandemi Süreci ve Normalleşme Dönemi}

İlk olarak Çin'in Wuhan kentinde ortaya çıkan, SARS-CoV-2 olarak adlandırılan virüs, COVID-19 olarak isimlendirilen hastalığa neden olan koronavirüs, SARS-CoV ve MERS-CoV gibi bir RNA virüs ailesindendir. Bu virüs ailesinin mutasyon becerilerinin yüksek olması ve ciddi hastalıklara yol açması nedeniyle bu tür virüslerin bulaşma riskini ve tehlike seviyesini daha da yükseğe taşımaktadır (Budak \& Korkmaz, 2020: 65-66). COVID-19 virüsü Dünya Sağlık Örgütü tarafından 11 Mart 2020'de küresel olarak etkisini göstermesi nedeniyle pandemi olarak ilan edilmiştir (Karataş, 2020: 5) . COVID-19 virüsünün kişiden kişiye bulaşması oldukça yüksektir. Virüsün bulaşma oranı ocak ayında artış göstermiș ve 13 Mart 2020 tarihinde COVID-19 virüsünün merkez üssü Avrupa olarak değișmiștir (Aslan, 2020: 39). COVID-19 pandemi süreci ile birlikte birçok ülke (Çin, İtalya, Fransa, İspanya, Amerika, Kanada gibi) virüsün yayılmasını önlemek amaciyla acil durum önlemleri almıştır. Bu kapsamda okullar, üniversiteler, kreşler, sinemalar, müzeler, restoranlar kapatılmıştır. Halka açık toplantılar ve etkinlikler iptal edilmiş, insanlar karantinaya alınmış, seyahat kısıtlamaları getirilerek sınırlar kapatılmış ve virüs bulaşma riski yüksek olan ülkelere uçuşlar iptal edilmiştir (Hamauche, 2020: 3).

Türkiye'de ilk koronavirüs vakası 11 Mart 2020 tarihinde görülmüştür. Cumhurbaşkanlığı olmak üzere hükümetin ilgili kurum ve kuruluşları bu süreçte gerekli tedbirlerin uygulanması adına aşamalı olarak kararlar almıştır. Alınan bu kararlar dünyada olduğu gibi Türkiye'de de sosyal, ekonomik ve kültürel alanlarda önemli değişikliklere neden olmuştur. COVID-19 pandemisinin birçok ülkede etkili olması yanında Türkiye' de de henüz vaka sayısının olmadığı ilk dönemde Sağlık Bakanlığı COVID-19 pandemisi ile mücadele amacıyla, 10 Ocak 2020 tarihinde 31 kișiden oluşan bilim kurulunu kurmuş ve sonrasında pandemi sürecinin lokomotifi olarak tüm devlet birimlerini yönlendirmiştir. Bu bağlamda Sağlık Bakanlığınca, 11 Mart 2020 tarihinde yapılan açılama ile evde 14 gün karantina uygulanması tavsiye edilmiş, 14 Mart 2020 tarihinde Korona Danışma Hattı (SABİM-184), 19 Mart 2020 tarihinde koronavirüs kontrolü için internet sitesi kurulmuştur (Sağlık Bakanlığ $1,2020_{\mathrm{a}}$ ). Aynı tarihte bilim kurulu tavsiyesi ile restoranlarda masalar arası mesafenin en az 1 metre olmasına yönelik tedbir kararı alınmışıtır. Bu karardan iki gün sonra konaklama tesisleri, restoranlar, yurtlar ve huzurevi gibi toplu mekânları ayrıca morg ve defin hizmetlerini de içeren yeni tedbirler alınmıştır (Sağlık Bakanlığı, 2020b). 19.03.2020 tarih ve 2020/3 sayılı Genelge ile her türlü bilimsel, kültürel, sanatsal ve benzeri toplantılar ve aktiviteler ertelenmiştir (Resmi Gazete, Sayı: 31074, 2020).

Milli Eğitim Bakanlığınca eğitim konusunda da bir takım tedbirler alınmış ve bunlardan en önemlisi; Türk eğitim tarihinde bir ilk olan örgün eğitimin tamamen uzaktan eğitim şekilde verilmesine dair karardır. Bu karar ile 16 Mart'tan itibaren ilkokul, ortaokul ve lise eğitimine 1 hafta, üniversite eğitimine ise 3 hafta ara verileceği, haftalık ders programlarının yapılandırılarak, 23 Mart'tan itibaren uzaktan eğitimle EBA, internet ve TRT ile televizyondan eğitim öğretime devam edileceği belirtilmiştir. Ayrıca Milli Eğitim Bakanlığı (MEB) kadrolarında görev yapan aday (sözleşmeli/kadrolu) öğretmenlerin adaylık kaldırma sınavı, bursluluk ve Motorlu Taşıt Sürücü Kursiyerleri (MTSK) sınavları ertelenmiştir (Milli Eğitim Bakanlığı, 2020).

İçişleri Bakanlığı özellikle Cumhurbaşkanlığı genelgelerinin uygulayıcısı niteliğinde genelgeler çıkararak, kamu ve özel sektör çalışma alanlarında, Cumhurbaşkanlığı'ndan sonra en kapsamlı düzenlemeleri yapmıştır. Bakanlık bu bağlamda 15-16.03.2020 tarihlerinde ilk genelgelerini çıkarmıştır (İçişleri Bakanlığı, 2020a ; İçişleri Bakanlığı, 2020 b) 81 ilin valiliğine gönderilen genelgeler ile Umuma Açık İstirahat ve Eğlence Yerleri olarak faaliyet yürüten işyerlerinin faaliyetleri geçici olarak durdurulmuştur. Başka bir genelge ile berber, kuaför, güzellik merkezlerinin faaliyetleri 21.03.2020 tarihi itibariyle geçici süreliğine durdurulmuştur (T.C. İçişleri Bakanlığ $1,2020_{\mathrm{c}}$ ). İçişleri Bakanlığ tarafindan ticari taksilerin (İçişleri Bakanlığ $1,2020_{\mathrm{d}}$ ) ve pazar esnafının (İçişleri Bakanlığı, 2020 ) çalışma şartlarını düzenleyen iki ayrı genelge çıkarılmıştır. 
Hazine ve Maliye Bakanlığ 1 tarafindan da kamu personeli ve özel sektör düzeyinde çalışanlara yönelik mali alanlarda bir takım düzenlemeler yapılmıştır. 25.03.2020 tarihinde Bakanlık, üç kamu bankası ile kurumsal ve ticari ölçekteki firmaların işletme sermayesi ihtiyaçları için "İ̧e Devam Kredi Desteği"ni hayata geçireceğini duyurarak 26.03.2020 tarihinde Bakanlık Ekonomik İstikrar Kalkanı ile ekonominin canlı kalması adına firmalara maliyet ve istihdam desteği sağlamak için kısa çalışma desteği programını açıklamıştır. Bu bağlamda kısa çalışma ödeneği başvuruları Türkiye İş Kurumu (İŞKUR) bünyesinde alınmıştır. 12.04.2020 tarihinde yapılan açıklamada, kısa çalışma ödeneğinden yararlanamayan yahut bu süreçte ücretsiz izne çıkarılan vatandaşlara aylık 1170 lira maaş desteği sağlanacağı açıklanmıştır. (Hazine ve Maliye Bakanlığı, 2020).

Yapılan bu düzenlemeler yanında sosyal ve ekonomik hayatın canlılığı ve devamı için normalleşme planı yapılarak COVID-19 pandemisinin yurt içinde ve yurt dışında seyrine bağlı olarak yürütülmesi planlanmış ve bu bağlamda Cumhurbaşkanlığınca genel kısıtlamaların kaldırılması, çalışma hayatı, psikososyal destekler, sağlık hizmetleri, eğitim, din hizmetleri, savunma, sanayi hizmetleri, sanayi kuruluşları ve esnaflar, ticaret, turizm, kültürel etkinlikler, gıda, tarım ve orman, spor, gençlik, çevre ve şehircilik hizmetleri, ulaştırma, dışişleri, enerji, düzensiz göçmenler ve geçici koruma altındakiler alanlarında normalleşme adımları belirlenmiştir. 1 Haziran 2020 tarihinden itibaren normalleşme planı ile yeniden düzenlemeler yapılmıştır. $\mathrm{Bu}$ yeniden düzenlemelerden bazıları; sokağa çıkma yasağının, şehirlere giriş-çıkışların sınırlamasının kaldırılması, salgının kontrol altına alındığı ülkelere sınır kapılarının, avm-kafe-restoran gibi yerlerin ve sosyal alanların açılması gibi bir takım sosyo ekonomik düzenlemelerdir. Ayrıca çalışma hayatına yönelik alınmış olan önlemlerin kaldırılması ya da regüle edilmesi ile ilgili düzenlemeler de yapılmıştır. Bu bağlamda kamuda idari izin büyük ölçüde kaldırılmış yeni düzenlemeler getirilmiştir. Bu süreçte esnek çalışma modeli ise kaldırılmıştır. Yine yabancı çalışanlarla ilgili düzenlemeler yapılmıştır. İş veya hizmet sözleşmelerinin feshedilmesine ilişkin kısıtların kaldırılması, kısa çalışma uygulamasının COVID19 tedbirleri kapsamından çıkarılması gibi düzenlemeler yapılmıştır. (Cumhurbaşkanlığ 1,2020 ).

Ekonomik hayatı düzenlemek adına 1 Haziran 2020 tarihinde Hazine ve Maliye Bakanlığı'nın açıkladığı konut, taşıt, tatil ve sosyal hayatı destek kredi paketleri kamu bankası olan Ziraat Bankası, Halkbank ve Vakıfbank tarafından açıklanmıştır. Makalenin konusu gereği bu dört kredi paketinden sadece konut kredisi hakkındaki açılamalara yer verilmektedir (Hazine ve Maliye Bakanlığ 1,2020$)$.

Emlak piyasasına canlılık getirmiş olan konut kredi paketini açıklayan bankalar; Ziraat Bankası, Halkbank ve Vakıfbank müşterilerine sıfır veya ikinci el konut satın alımlarının finansmanına yönelik konut kredisi paketi açıklamıştır. Bu kapsamda sıfır veya ikinci el konutlar için, azami 500 Bin TL'ye kadar (500 Bin TL dâhil ), sıfir konutlarda 0,64 faiz oranıla 180 ay, ikinci el konutlarda ise 0,79 faiz oranıla 120 aya kadar vade ile konut finansmanı imkânı sunmaktadır. Bununla beraber mezkûr bankalar İstanbul, Ankara ve İzmir'de azami kredi tutarı sınırını 750 Bin TL olarak belirlemişlerdir (Ziraat Bankası 2020; Vakıfbank, 2020). Halkbank ayrıca sıfır konutlarda 12 aya kadar ödemesiz dönem imkânı da sunmaktadır. (Halkbank, 2020).

Kredi ile yapılan gayrimenkul satışlarında, alınan gayrimenkulün ya da başka bir gayrimenkulün üzerine ipotek koyulmaktadır. Buna ipotekli satış denilmektedir. İpotek bankanın verdiği krediye karşı aldığı teminattır (TKGM, 2014). Konut kredi paketinin açıklanmasına paralel emlak piyasasında ipotekli konut alım satım işlemleri artmıştır. Bunun bir neticesi olarak Tapu Müdürlüklerinde işlem hacmi de artmıştır. 


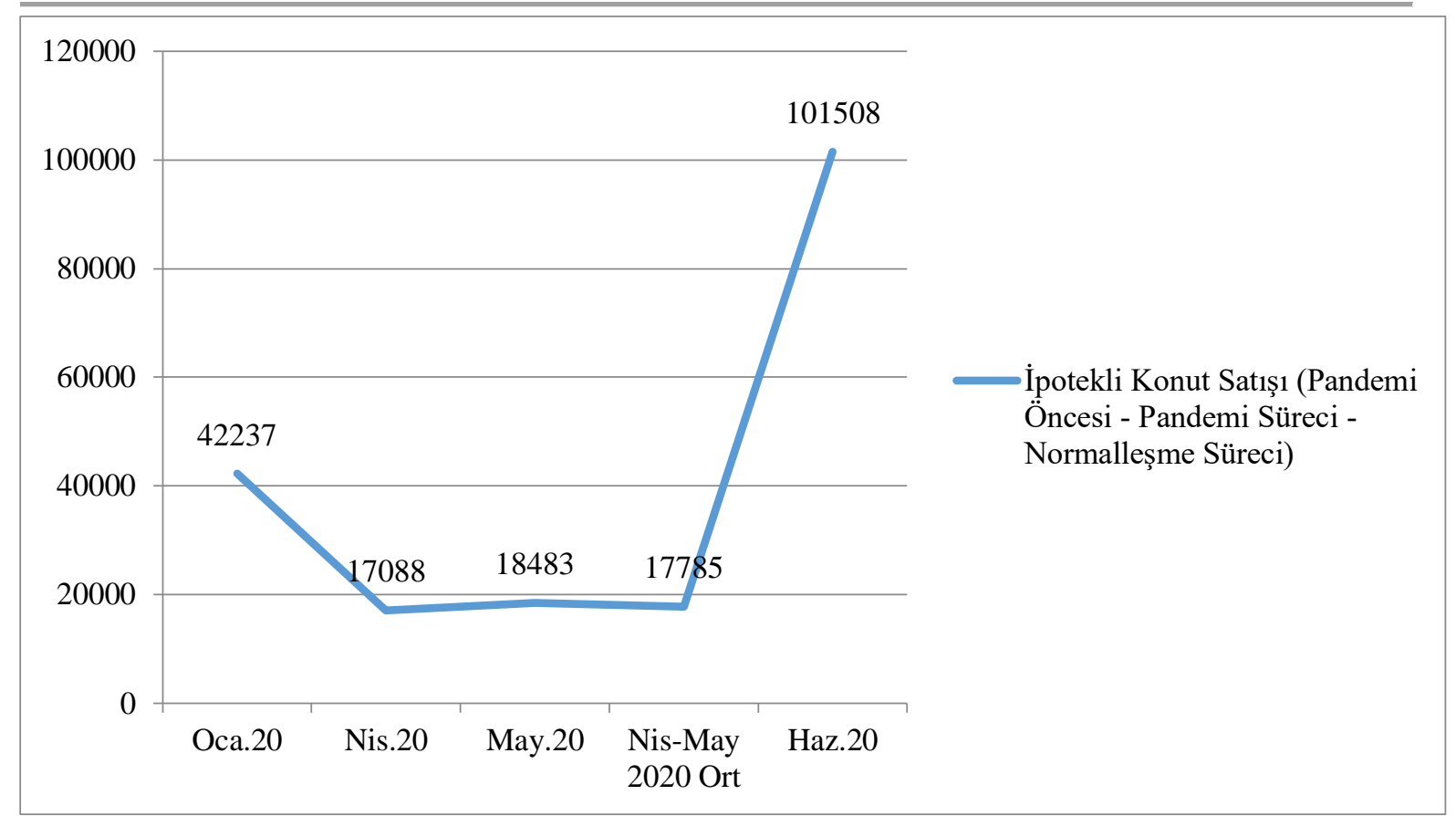

Grafik 1: İpotekli Konut Satışı (COVID-19 Pandemi Öncesi - COVID-19 Pandemi Süreci-Normalleşme Dönemi)

TÜİK verilerine göre COVID-19 pandemi ilanından kısa bir zaman önce 2020 yılının Ocak ayında ipotekli konut satı̧s sayısı 42237 iken, pandemi sürecinde bu rakam Nisan ayında 17088, Mayıs ayında 18483 olmuştur. Kredi destek paketinin açıklanması sonrasında ise ipotekli konut satış1 Haziran ayında 101508'e çıkmıştır. Pandemi yasaklarının katı bir şekilde uygulandığı nisan ve mayıs aylarının ipotekli konut satış ortalaması 17785 iken normalleşme sürecinde kredi destek paketinin uygulanmasına paralel bu sayı haziranda diğer iki aydaki değerinden yaklaşık 5,7 kat fazladır. İpotekli konut satış sayısındaki bu artış, tapu müdürlüklerindeki işlem sayılarının da aynı oranda arttığının bir göstergesidir (TÜİK, 2020). Bunun sonucu olarak özellikle Tapu Müdürlükleri’ne bağlı çalışan personelin iş yükü pandemi süreci ve normalleşme döneminde artış göstermiştir.

\section{COVID-19 Pandemi Süreci ve Normalleşme Döneminde Çalışma Hayatında Alınan Önlemler ve Kamu Çalışanlarına Yönelik Düzenlemeler}

Küresel çapta ya da ülke bazlı yaşanan krizler yapıları itibariyle COVID-19 pandemisinin neden olduğu ekonomik krizden oldukça farklıdır. COVID-19 pandemisi insan odaklı olup tüm dünyada olduğu gibi pandeminin neden olduğu krizin etkileri Türkiye'yi de etkilemiştir (Balcı \& Çetin, 2020: 43). Türkiye COVID-19 pandemi sürecinde ve normalleşme döneminde çalışma hayatına ilişkin tedbirler ve önlemler almıştır. Her ne kadar COVID-19 pandemisi ve bunun ortaya çıkardığı olumsuz etkileri önlemek amacıyla kararlar alınsa da toplumda pek çok kesim işsiz, gelirsiz ve korumasız bir durumla karşı karşıya kalmıştır. COVID-19 pandemi sürecinden doğrudan ya da dolaylı olarak ortaya çıkan istihdam ve gelir kaybı devletin mutlak koruma kapsamı içerisinde yer alan bireyler için söz konusu değildir. Bunlar Türkiye'de sayıları yaklaşık olarak 26,4 milyon kişidir. 5510 sayılı Sosyal Sigortalar ve Genel Sağlık Sigortası Kanunu(SGK)'na göre bu kapsamda devlet memurları (4/c), kamu kesiminde çalışan işçiler(4/a), bu iki grubun bakmakla yükümlü olduğu kişiler ve emekliler yer almaktadır (Yükseler, 2020: 2).

COVID-19 pandemi sürecinde Cumhurbaşkanlığ 1 ve tüm bakanlıklarca, hem kamu hem de özel sektör çalışanlarına yönelik birtakım düzenlemeler yapılmıştır. Bu düzenlemeler: 
- 13.03.2020 tarih ve 2020/2 sayılı Genelge ile kamu görevlilerinin yurtdışına çıkış1 yasaklanmıştır (Resmi Gazete, Sayı: 31067, 2020).

- 22.03.2020 tarih ve 2020/4 say1lı Genelgeyle ihtiyacı karş1layacak kadar asgari personelin bulundurulması şartıyla, çalıştırılma biçimine bakılmaksızın kamu kurum ve kuruluşlarında çalışanlara, uzaktan çalışma, dönüşümlü çalışma gibi esnek çalışma yöntemi uygulanabilmesine ve idari izin verilmesine (Resmi Gazete, Say1: 31076, 2020);

- Cumhurbaşkanlığı 2020/4 sayılı genelgesine istinaden İçişleri Bakanlığ kendi personelinin esnek çalışması ile ilgili Bakanlık Merkez Birimine ve 81 İl Valiliğine 23.03.2020 tarihinde resmi yazı göndermiştir (İçişleri Bakanlığı, 2020f).

- Hazine ve Maliye Bakanlığı ise kendi personeline yönelik, 25.03.2020 tarih ve 221415 sayılı yazısı ile esnek çalışma modeline geçmiştir.

- Milli eğitim bakanlığı 23.03.2020 tarihinde EBA sistemi ile uzaktan eğitim modeline geçerek tüm öğretmenlerin bu kapsamda çalışmasını temin etmiştir.

- 27 Mart 2020 tarihli Genelgeyle Sağl1k Bakanlığı, kamu ve özel sektöre ait tüm sağlık kurumlarında çalışan sağlık personelinin ayrılış (istifa) işlemleri 3 ay boyunca durdurulmuştur.

- YÖK 13.03.2020 tarihinde yayımladığ genelge ile riskli gurupta bulunan personele 16.03.2020 tarihinden itibaren 12 gün idari izin vermiştir. Aynı genelgede personele yurtdışına çıkış yasağına karar verilmiştir (YÖK, 2020).

- 18.03.2020 tarihinden itibaren Tapu ve Kadastro Müdürlüklerine yapılan başvuruların web-tapu sistemi üzerinden (https://webtapu.tkgm.gov.tr) yapılacağı duyurulmuştur (TKGM, $2020_{\text {c). }}$

- 29.05.2020 tarih ve 2020/8 sayılı Genelge ile kamu kurum ve kuruluşlarında normalleşme sürecinde alınacak tedbirler ile 2020/4 sayılı Genelgede alınan kararların normalleşme sürecinde yenilenmesine yönelik kararlar verilmiştir. Bu bağlamda 2020/2 ve 2020/4 say1lı genelgeler yürürlükten kaldırılmıştır (Resmi Gazete, Sayı: 31139). Tüm kamu kurumları bu genelge çerçevesinde esnek çalışma modelinden normal çalışma modeline geçmiştir.

Normalleşme süreci Cumhurbaşkanlığ 1 organizasyonunda gerçekleştirilmiştir. Bu görev Cumhurbaşkanı Yardımcılığına verilmiştir. Çalışma hayatında yapılacak değişiklikler "COVID-19 Normalleşme Planı" çerçevesinde gerçekleştirilmiştir. Bu bağlamda 20 Mayıs 2020 tarihinden itibaren tüm kamu personelinin esnek çalışma modelinin normal çalışma modeline geçişi ve Sağlık Bakanlığı'nın belirlediği idari izinli kapsamı dışında yer alan idari izinlerin kaldırılması ile ilgili süreç başlatılmıştır. 5 Mayıs 2020 tarihinden sonra Tapu Müdürlüklerinde yapılan işlem türü kısıtlamalarının kaldırılması ve ara verilen çalışmaların tekrar başlatılması gündeme alınmıştır. 1 Temmuz 2020 itibariyle Sağlık Bakanlığı personelinin durdurulan izinlerinin kademeli olarak kaldırılması ve personelin tayin ve yer değişikliği uygulamalarının normale dönmesine karar verilmiştir (Cumhurbaşkanlığ 1,2020 ).

\section{Araştırmanın Metodolojisi}

\section{Araştırmanın Amacı ve Önemi}

$\mathrm{Bu}$ araştırmanın amacı, COVID-19 pandemi süreci ve normalleşme döneminde kamu çalışanlarının aktif olarak çalışması nedeni ile COVID-19 pandemi süreci ve normalleşme döneminde pandemi karşısındaki tutumlarının ölçülmesidir. Araştırmanın örneklemi Tapu Kadastro ve Genel Müdürlüğü'ne bağlı çalışanlardan oluşmaktadır. COVID-19 pandemi süreci ve normalleşme döneminde Tapu Kadastro ve Genel Müdürlüğü’ne bağlı personelin çalıştıkları kurumda vatandaşla sürekli iletişim halinde olmaları ve normalleşme döneminde açıklanan ekonomik paket çerçevesinde daireye gelen vatandaşların artış göstermesi ve iş yüklerinin daha da 
artması onların virüsle karşı karşıya kalma olasılıklarını artırmaktadır. Yapılan literatür araştırmasında, pandemi sürecinde kamu çalışanlarının bu süreçten nasıl etkilendiği ve pandemi karşısındaki tutumlarının ne olduğu konusuna ilişkin sınırlı sayıda çalışma olduğu görülmüştür. Yapılan bu çalışma sonucunda ortaya çıkan sonuçların yapılacak çalışmalara da örnek olacağı umulmaktadır.

\section{Evren ve Örneklem}

Araştırmanın evreni Türkiye'de Tapu Kadastro ve Genel Müdürlüğü'ne bağlı kamu personelidir. Bugünkü adıyla Tapu ve Kadastro Genel Müdürlüğü (TKGM) tarihi, Osmanlı İmparatorluğu'na dayanan, eski ve köklü kurumlardan biridir. İlk olarak 1847 y1lında Defterhane-i Amire Kalemi adıyla kurulmuştur. Türkiye Cumhuriyeti'nin kurulmasına müteakiben 1924 yılında Tapu Umum Müdürlüğü Teşkilatı kurulmuştur. Bu teşkilatın bünyesine 1925 yılında 658 sayılı Kanunla kadastro birimi ilave edilmiştir. Tapu ve Kadastro Genel Müdürlügünün bugünkü yapısı 29 Mayıs 1936 tarih ve 2997 sayılı Kanunla belirlenmiş olup Teşkilat, Maliye Bakanlığına bağlanmıştır. Daha sonra, 7 Temmuz 1939 tarihinde Adalet Bakanlığına, 10 Ağustos 1951 tarihinde Başbakanlığa, 22 Kasım 2002 tarihinde Bayındırlık ve İskân Bakanlığına ve nihai olarak 08 Temmuz 2011 tarihinde de Çevre ve Şehircilik Bakanlığına bağlanmıştır (TKGM, 2020a).

Toplamda 19254 personele sahip olan TKGM'nin teşkilat yapısı Merkez ve Taşra teşkilatından oluşmaktadır. 1184 personeli olan merkez teşkilatı; 12 Daire Başkanlığı, Hukuk Müşavirliği ve Döner Sermaye İşletme Müdürlügünden oluşmaktadır. Bu birimde bulunan kadrolar; Genel Müdür ve Yardımcıs1, Daire Başkanı, Tapu Kadastro Uzmanı, Şube Müdürü, Mühendis, Teknik Personel, Bilgisayar İşletmeni, Memur ve İşçi kadrolarıdır. Taşra Teşkilatı ise 1359 personele sahip olan 24 Bölge Müdürlüğü, 5027 personeli olan 81 Kadastro Müdürlüğü ve 11684 personeli ile kurum içinde en fazla personel barından 973 Tapu Müdürlüğü’nden oluşmaktadır. Bu birimlerde bulunan kadrolar ise; Bölge Müdürü, Tapu Müdürü, Kadastro Müdürü, Tapu Müdür Yrd, Teknik Personel, Bilgisayar İşletmenidir. (TKGM, 2020b).

Örneklem seçiminde ulaşılabilirlik açısından verilerin normal dağılımı göz önüne alınarak rastgele örnekleme yöntemi kullanılmıştır. Anket formu, Genel Müdürlük, Bölge Müdürlüğü, Tapu Müdürlüğü, Kadastro Müdürlüğü'ne bağlı merkez ve taşra teşkilatında bulunan 19254 görevli personele Tapu ve Kadastro Genel Müdürlüğü aracılığıyla internet üzerinden ulaştırılmış, toplamda 2859 personelden geri dönüş alınmıştır. Hazırlanan anket formu 02-14 Temmuz 2020 tarihleri arasında uygulanmış ve çalışma verileri Bandırma Onyedi Eylül Üniversitesi Sosyal ve Beşeri Bilimler Etik Kurulu'nun 26.06.2020 kayıt tarih ve 4585 sayısı ile onaylanmıştır.

Çalışmada, Yılmaz (2020) tarafından geliştirilen "Kamu çalışanlarının pandemi karşısındaki tutum ölçeği” kullanılmıştır. Ölçek 5'li Likert tipinde toplamda 20 maddeden oluşmakta ve "pandemide bireysel tutum", "pandemide örgütsel tutum" olmak üzere 2 faktörden oluşmaktadır. Ölçeğin güvenilirlik analizi \%97,4'tür. Bu çalışmada ise "Kamu çalışanlarının pandemi karşısındaki tutum ölçeği" soruları değiştirilmeden anketteki demografik bilgilere ait sorular 13 maddeye çıkarılmıştır. Böylece toplamda 33 soru ile anket formu son halini almıştır. Ölçek sorularının cevapları "kesinlikle katılıyorum, katılıyorum, kararsızım, katılmıyorum, kesinlikle katılmıyorum" 5'li Likert halindedir.

\section{Verilerin Analizi}

Verilerin değerlendirilmesinde SPSS paket programından faydalanarak tanımlayıcı istatistikler ve faktör analizi kullanılmıştır. Güvenilirlik analizi sonucu \%86,9 değerine ulaşılmıştır. Kullanılan "Kamu çalışanlarının pandemi karşısındaki tutum ölçeği" ile geliştirilen 2 faktöre yeni faktör eklenerek toplamda 3 faktörden oluşarak ölçek son halini almıştır. COVID-19 pandemi sürecinde bireysel tutum, örgütsel tutumdan oluşan ölçek normalleşme dönemi ile birlikte ortaya çıan sonuçla birlikte 3 . faktör olarak çalışma tutumu şeklindedir. 


\section{Bulgular}

Çalışmanın örneklem grubunu oluşturan bireylerin demografik bulguları Tablo 1'de gösterilmiştir.

Tablo 1: Demografik Bulgular

\begin{tabular}{|c|c|c|}
\hline Cinsiyetiniz & Frekans & Frekans \% \\
\hline Kadın & 945 & $33,1 \%$ \\
\hline Erkek & 1914 & $66,9 \%$ \\
\hline Toplam & 2859 & $100 \%$ \\
\hline Doğum Yılı Aralığınız & Frekans & Frekans \% \\
\hline 1945-1964 & 211 & $7,4 \%$ \\
\hline $1965-1979$ & 958 & $33,5 \%$ \\
\hline 1980-1994 & 1444 & $50,5 \%$ \\
\hline 1995 ve sonrası & 246 & $8,6 \%$ \\
\hline Toplam & 2859 & $100 \%$ \\
\hline Ĕ̈itim Düzeyiniz & Frekans & Frekans\% \\
\hline Ortaöğretim & 51 & $1,8 \%$ \\
\hline Lise & 257 & $9 \%$ \\
\hline Lisans & 2263 & $79,2 \%$ \\
\hline Lisansüstü & 288 & $10,1 \%$ \\
\hline Toplam & 2859 & $100 \%$ \\
\hline Medeni Durumunuz & Frekans & Frekans\% \\
\hline Bekâr & 696 & $24,3 \%$ \\
\hline Evli & 2163 & $75,7 \%$ \\
\hline Toplam & 2859 & 100 \\
\hline Çalıştığınız Birim & Frekans & Frekans\% \\
\hline Genel Müdürlük & 92 & $3,2 \%$ \\
\hline Bölge Müdürlüğü & 120 & $4,2 \%$ \\
\hline Tapu Müdürlüğü & 2245 & $78,6 \%$ \\
\hline Kadastro Müdürlüğü & 398 & $13,9 \%$ \\
\hline Kayıp Veri & 4 & $0,1 \%$ \\
\hline Toplam & 2859 & $100 \%$ \\
\hline Kurumda Çalıştı̆ğınız Pozisyon & Frekans & Frekans\% \\
\hline Müdür & 349 & $12,2 \%$ \\
\hline Müdür Yardımcısı & 274 & $9,6 \%$ \\
\hline Uzman & 64 & $2,2 \%$ \\
\hline Mühendis & 103 & $3,6 \%$ \\
\hline Memur & 325 & $11,4 \%$ \\
\hline Bilgisayar İşletmeni & 803 & $28,1 \%$ \\
\hline Teknik Personel & 692 & $24,2 \%$ \\
\hline Diğer & 249 & $8,7 \%$ \\
\hline Toplam & 2859 & $100 \%$ \\
\hline Çalışma Yılınız & Frekans & Frekans\% \\
\hline $1-4 \mathrm{y} 1 \mathrm{l}$ & 567 & $19,8 \%$ \\
\hline $5-9$ y1l & 574 & $20,1 \%$ \\
\hline 10 yll ve üstü & 1718 & $60,1 \%$ \\
\hline
\end{tabular}




\begin{tabular}{ccc}
\hline Toplam & 2859 & $100 \%$ \\
\hline $\begin{array}{c}\text { Bulunduğunuz Kurumda } \\
\text { Çalışma Yılınız }\end{array}$ & Frekans & Frekans\% \\
\hline $1-4$ yıl & 1193 & $41,7 \%$ \\
$5-9$ yil & 727 & $25,4 \%$ \\
10 yıl ve üstü & 939 & $32,8 \%$ \\
\hline Toplam & 2859 & $100 \%$ \\
\hline
\end{tabular}

Tablo 1'e göre; ankete katılan 2859 personelin \%66,9'u erkek, \%33,1'i kadındır. Doğum yılı aralıkları ise; 1945-1964 yılları arasında doğanlar \%7,4, 1965-1979 yılları arasında doğanlar \%33,5 ve 1980-1994 yılları arası doğanlar ise \%50,5 ile çoğunluğu oluşturmaktadır. 1995 ve sonrasında doğanların oranı ise \%8,6'dır. Eğitim durumları incelendiğinde; \%1,8'i Ortaöğretim, \%9'u Lise, \%79,2'si Lisans ve \%10,1 ile Lisansüstüdür. Medeni durumları ise \%24,3 ile bekâr, \%75,7 ile evlilerden oluşmaktadır. Anketi cevaplayan personelin kurumda çalıştıkları birim incelendiğinde; Genel Müdürlükte çalışanların oranı \%3,2, Bölge Müdürlüğünde çalışanların oranı \%4,2, Tapu Müdürlüğünde \%78,6 ve Kadastro Müdürlüğünde \%13,9'dur. Toplamda 2859 personelin \%0,1'i (4 kişi) bu soruyu cevapsız bırakmıştır. Anketi cevaplayan personelin kurumda çalıştıkları pozisyonlar incelendiğinde; \% 12,2'si Müdür, \%9,6's1 Müdür Yardımcıs1, \%2,2'si Uzman, \%3,6's1 Mühendis, \%11,4'ü Memur, \%28,1'i Bilgisayar İşletmeni, \%24,2'si Teknik Personel, \% 8,7'si Diğer personelden oluşmaktadır. Çalışma yılı sorusuna verilen cevapların oranı, 1-4 yıl \%19,8, 5-9 yı1 $\% 20,1,10$ yıl ve üstü \%60,1'dir. Bulunduğunuz kurumda çalışma yılınız sorusuna verilen cevapların oranı ise 1-4 y1l \%41,7, 5-9 y1l \%25,4, 10 y1l ve üstü \%32,8'dir.

Anket soruları içinde yer alan COVID-19 pandemi süreci ve normalleşme dönemine ilişkin sorulan sorulara ait bulgular Tablo 2'de gösterilmiştir. 
Tablo 2: COVID-19 Pandemi Süreci ve Normalleşme Dönemi Sorularına İlişkin Bulgular

\begin{tabular}{|c|c|c|}
\hline $\begin{array}{l}\text { Size COVID-19 teşhisi konuldu } \\
\text { mu? }\end{array}$ & Frekans & Frekans \% \\
\hline Evet & 19 & $0,7 \%$ \\
\hline Hayır & 2840 & $99,3 \%$ \\
\hline Toplam & 2859 & $100 \%$ \\
\hline $\begin{array}{l}\text { Çevrenizde bulunan } \\
\text { biri/ birilerine COVID-19 teşhisi } \\
\text { konuldu mu? }\end{array}$ & Frekans & Frekans \% \\
\hline Evet & 710 & $24,8 \%$ \\
\hline Hayır & 2149 & $75,2 \%$ \\
\hline Toplam & 2859 & $100 \%$ \\
\hline $\begin{array}{l}\text { COVID-19 pandemisi nedeniyle } \\
\text { idari izin kullandıız mı? }\end{array}$ & Frekans & Frekans\% \\
\hline Evet & 1197 & $41,9 \%$ \\
\hline Hayır & 1662 & $58,1 \%$ \\
\hline Toplam & 2859 & $100 \%$ \\
\hline $\begin{array}{l}\text { Yeni dönemde kredi destek } \\
\text { paketi içinde yer alan konut } \\
\text { kredisine bağlı olarak iş } \\
\text { yükünüz arttı mı? }\end{array}$ & Frekans & Frekans\% \\
\hline Evet & 2478 & $86,7 \%$ \\
\hline Hayır & 364 & $12,7 \%$ \\
\hline Kayıp Veri & 17 & $0,6 \%$ \\
\hline Toplam & 2859 & 100 \\
\hline $\begin{array}{l}\text { Cevabınız Evet ise kurumunuza } \\
\text { gelen vatandaşların sizin için } \\
\text { virüs riski oluşturduğunu } \\
\text { düşünüyor musunuz? }\end{array}$ & Frekans & Frekans\% \\
\hline Evet & 2628 & $97,3 \%$ \\
\hline Hayır & 72 & $2,7 \%$ \\
\hline Toplam & 2700 & $100 \%$ \\
\hline
\end{tabular}

Tablo 2'ye göre; ankete katılanların \%0,7'sine (19 kişi) COVID-19 teşhisi konulmuş \%99,3'üne (2840 kişi) ise teşhis konulmamıştır. Çevrenizde bulunan biri ya da birilerine COVID-19 teşhisi konuldu mu? sorusuna ise \%24,8'i evet \% 75,2'si ise Hayır cevabını vermiştir. COVID-19 pandemi nedeniyle idari izin kullandınız mı? sorusuna ankete katılan personelin \%41,9'u evet, $\% 58,1$ ' $i$ ise hayır cevabını vermiştir. Yeni dönemde kredi destek paketi içinde yer alan konut kredisine bağlı olarak iş yükünüz arttı mı? sorusuna verilen cevaplar incelendiğinde ankete katılan personelin \%86,7 ile evet cevabını vererek çoğunluğu oluşturduğu görülmektedir. Hayır cevabını verenlerin oranı ise \%12,7'dir. Bu soruyu katılımcıların \%0,6'sı cevap vermeyerek boş bırakmıştır.

Cevabınız Evet ise kurumunuza gelen vatandaşların sizin için virüs riski oluşturduğunu düşünüyor musunuz? sorusuna \%97,3'ü evet, \% 2,7'si hayır cevabını vermiştir. Yeni dönemde kredi destek paketi içinde yer alan konut kredisine bağlı olarak iş yükünüz arttı mı? sorusuna cevabı evet olanlarla birlikte hayır olanlarında cevap verdiği görülmektedir. Bu sonuçlara göre; Tapu Kadastro Genel Müdürlügü’ne bağlı çalışan anket katılımcıları, kredi destek paketleri ile iş yüklerinin arttığını aynı zamanda artan bu yükle birlikte kredi destek paketinden yararlanmak isteyen ve bunun için kuruma gelen vatandaşların, kendileri için virüs riski oluşturduğunu ifade etmektedir. 


\section{COVID-19 Pandemi Süreci ve Normalleşme Döneminde Kamu Çalışanlarının Pandemi Karşısındaki Tutum Ölçeği}

Yılmaz'ın (2020) Gelir İdaresi Başkanlığına bağlı İstanbul Vergi Dairesi Başkanlığı bünyesinde çalışan 902 personelle yapmış olduğu çalışmada geliştirilen ölçek bu çalışmada normelleşme dönemi ile birlikte Tapu ve Kadastro Genel Müdürlüğü'ne bağlı çalışan personelin pandemi karşısındaki tutumlarını ölçmek amacıyla yeniden değerlendirilmiştir. İş yoğunluğu yüksek olan kamu dairelerinin COVID-19 pandemi süreci ve normalleşme dönemi ile birlikte pandemi karşısındaki tutumlarının ne olduğu konusunun karşılaştırılması önemlidir. Bu nedenle, bu çalışmada "Kamu çalışanlarının pandemi karşısındaki tutum ölçeği" kullanılmıştır. Çalışmada elde edilen bulgular faktör analizi ile değerlendirilmiştir.

Tablo 3: Güvenilirlik Analizi

\begin{tabular}{ccc}
\hline \multicolumn{2}{c}{ Cronbach Alfa Değeri } & Soru Sayısı \\
\hline 0,869 & 20 \\
\hline Tablo & 3 'te $\quad \alpha=0,869$ değeri anketi cevaplayanların COVID-19 pandemi süreci ve
\end{tabular}
normalleşme döneminde "Kamu çalışanlarının pandemi karşısındaki tutum ölçeği" daha güçlü hale getirmek amaciyla oluşturulan 20 sorunun faktör analizine uygun olduğunu göstermektedir.

Tablo 4: KMO ve Bartlett Testi Sonuçları

\begin{tabular}{ccc}
\hline $\begin{array}{c}\text { KMO Örnekleme Yeterlilik } \\
\text { Testi }\end{array}$ & & 0,913 \\
\hline Bartlett Küresellik Testi & Yaklaşık Ki-Kare & 30156,571 \\
\cline { 2 - 3 } & Serbestlik Derecesi & 190 \\
\cline { 2 - 3 } & p Değeri & 0,000 \\
\hline
\end{tabular}

Tablo 4'te KMO (Kaiser-Meyer-Olkin) test değeri 0,91 olarak hesaplanmış ve bu sonuç anket sorularının "mükemmel" seviyede faktör analizine uygun olduğunu ifade etmektedir. Faktör analizinin uygunluğunun belirlenmesi amacıyla yapılan KMO ve Barlett testinde KMO değerinin yüksek olması ölçekte her bir değişkenin diğer değişkenler tarafından mükemmel şekilde tahmin edilmesi olarak açıklanır (Kaya, 2013: 180). KMO indeks aralığı 0.50'nin altında ise "kabul edilemez", 0.50-0.60 ise "kötü", 0.60-0.70 ise "zaylf", 0.70-0.80 ise "orta", 0.80-0.90 ise "iyi", 0.90 üzerinde ise "mükemmel" çıkarımı yapılır. KMO değeri 1'e ne kadar yakın olursa eldeki verilerin de analize uygun olduğu kabul edilir (Gümüş \& Özgül, 2017: 869). Faktör analizinin önemli bir kriteri olan açıklanan varyans tablosunda da açıklanan varyansın toplam varyansın \%50'sini geçmesi gerekmektedir (Yaşlığlu, 2017: 77). Tablo 5'te Açıklanan Toplam Varyans değeri yer almaktadır. 
Tablo 5: Açıklanan Toplam Varyans

\begin{tabular}{|c|c|c|c|c|c|c|c|c|c|}
\hline & \multicolumn{3}{|c|}{ Başlangıç Özdeğerleri } & \multicolumn{3}{|c|}{$\begin{array}{c}\text { Kare Yüklemelerin } \\
\text { Ekstraksiyon Toplamları }\end{array}$} & \multicolumn{3}{|c|}{$\begin{array}{c}\begin{array}{c}\text { Kare Yüklemelerin Dönme } \\
\text { Toplamları }\end{array} \\
\end{array}$} \\
\hline & Toplam & $\begin{array}{c}\text { Varyansin } \\
\% \text { si }\end{array}$ & $\begin{array}{c}\text { Kümülatif } \\
\%\end{array}$ & Toplam & $\begin{array}{c}\text { Varyansin } \\
\% \text { si }\end{array}$ & $\begin{array}{c}\text { Kümülatif } \\
\%\end{array}$ & Toplam & $\begin{array}{c}\text { Varyans } \\
\% \text { si }\end{array}$ & $\begin{array}{c}\text { Kümülatif } \\
\%\end{array}$ \\
\hline 1 & 6,056 & 30,278 & 30,278 & 6,056 & 30,278 & 30,278 & 4,730 & 23,648 & 23,648 \\
\hline 2 & 4,598 & 22,991 & 53,269 & 4,598 & 22,991 & 53,269 & 3,690 & 18,448 & 42,095 \\
\hline 3 & 1,185 & 5,927 & 59,196 & 1,185 & 5,927 & 59,196 & 3,420 & 17,101 & 59,196 \\
\hline 4 & ,921 & 4,603 & 63,799 & & & & & & \\
\hline 5 & ,789 & 3,946 & 67,746 & & & & & & \\
\hline 6 & ,738 & 3,688 & 71,433 & & & & & & \\
\hline 7 & 663 & 3,313 & 74,746 & & & & & & \\
\hline 8 & 603 & 3,016 & 77,762 & & & & & & \\
\hline 9 & ,545 & 2,727 & 80,489 & & & & & & \\
\hline 10 & ,521 & 2,604 & 83,093 & & & & & & \\
\hline 11 & ,500 & 2,502 & 85,595 & & & & & & \\
\hline 12 & ,458 & 2,288 & 87,883 & & & & & & \\
\hline 13 & ,438 & 2,188 & 90,070 & & & & & & \\
\hline 14 & ,375 & 1,874 & 91,945 & & & & & & \\
\hline 15 & ,346 & 1,732 & 93,677 & & & & & & \\
\hline 16 & ,326 & 1,629 & 95,307 & & & & & & \\
\hline 17 & ,258 & 1,288 & 96,594 & & & & & & \\
\hline 18 & 252 & 1,260 & 97,854 & & & & & & \\
\hline 19 & ,219 & 1,093 & 98,947 & & & & & & \\
\hline 20 & 211 & 1,053 & 100,000 & & & & & & \\
\hline
\end{tabular}

Tablo 5'e göre ölçeğin açıklanan varyans değeri \%59,196 olduğu görülmektedir. Bu değerin alınmasında birinci boyutun varyans değeri \%23,648, ikinci boyut varyans değeri \%18,448 üçüncü boyut varyans değeri \%17,101'dir. Yapılan faktör analizinde faktör soruları Tablo 6'da yer almaktadır. 
Tablo 6: Döndürülmüş Bileşen Matrisi

\begin{tabular}{|c|c|c|c|}
\hline & 1 & 2 & 3 \\
\hline $\begin{array}{l}\text { Çalıştığım kurumda pandemi için gerekli önlemleri yeterli } \\
\text { buluyorum }\end{array}$ & 0,881 & & \\
\hline $\begin{array}{l}\text { Pandemi sürecinde çalışma ortamımı sağlıklı ve güvenilir } \\
\text { olduğunu düşünüyorum }\end{array}$ & 0,850 & & \\
\hline $\begin{array}{l}\text { Kurumumun yeterli düzeyde dezenfekte edildiğini } \\
\text { düşünüyorum. }\end{array}$ & 0,829 & & \\
\hline $\begin{array}{l}\text { Kurumda çalışanların sosyal mesafe kurallarına uyduğunu } \\
\text { düşünüyorum }\end{array}$ & 0,817 & & \\
\hline $\begin{array}{l}\text { Çalışma arkadaşlarımın sağlık ve güvenlik konusunda } \\
\text { gerekli önlemi aldığını düşünüyorum }\end{array}$ & 0,812 & & \\
\hline $\begin{array}{l}\text { Çalıştığım kurumda } \begin{array}{l}\text { COVID-19 } \\
\text { bilgilendirmelerin } \\
\text { bilgilendirme yazıları) }\end{array} \text { yapıldığını } \\
\text { düşünüyorum(afiş, }\end{array}$ & 0,775 & & \\
\hline $\begin{array}{l}\text { Pandemi sürecinde kurumumdan bilgilendirme eğitimi } \\
\text { aldım }\end{array}$ & 0,743 & & \\
\hline Her gün işe gelirken virüs bulaşma kaygısı duyuyorum & & 0,791 & \\
\hline $\begin{array}{l}\text { Her iş çıkışında eve gittiğimde aileme virüs bulaştırmaktan } \\
\text { korkuyorum }\end{array}$ & & 0,784 & \\
\hline $\begin{array}{l}\text { Daireye gelen vatandaşların bizim için risk oluşturduğunu } \\
\text { düşünüyorum }\end{array}$ & & 0,711 & \\
\hline $\begin{array}{l}\text { Pandemi devam ettikçe normal çalışma düzenine yeniden } \\
\text { dönmeyi uygun bulmuyorum }\end{array}$ & & 0,645 & \\
\hline $\begin{array}{l}\text { Pandemi sürecinde sağlığım yerinde olsa da işe geldiğimde } \\
\text { sürekli COVID-19 belirtileri varmış gibi hissediyorum }\end{array}$ & & 0,592 & \\
\hline $\begin{array}{l}\text { Kurumda uygun işlerin uzaktan çalışma şekline } \\
\text { dönüştürülmesi gerektiğini düşünüyorum }\end{array}$ & & 0,529 & \\
\hline $\begin{array}{l}\text { Pandemi sonrasi kurumumuzda psikolojik destek } \\
\text { programları uygulanmalı }\end{array}$ & & 0,502 & \\
\hline $\begin{array}{l}\text { Pandemi süreci çalışma motivasyonumu oldukça kötü } \\
\text { etkiledi }\end{array}$ & & & 0,792 \\
\hline Pandemi sürecinde çalışma performansım düştü & & & 0,786 \\
\hline $\begin{array}{l}\text { Pandemi sürecinde özel hayatım ve iş hayatım arasındaki } \\
\text { denge bozuldu }\end{array}$ & & & 0,784 \\
\hline Pandemi sürecinde uyku kalitem bozuldu & & & 0,742 \\
\hline $\begin{array}{l}\text { İnternette/sosyal medyada yer alan haberleri sürekli takip } \\
\text { ediyorum ve COVID-19 pandemisinin biteceğine dair } \\
\text { düşüncelerimi sürekli olumsuz etkiliyor }\end{array}$ & & & 0,513 \\
\hline $\begin{array}{l}\text { Çalışanlar içinde idari izinlilerin olması iş yükümü daha } \\
\text { çok artırdı }\end{array}$ & & & 0,430 \\
\hline
\end{tabular}

Tablo 6'da 3 faktöre ait tüm sorular yer almaktadır. Faktör 1'de yer alan sorular şunlardır: "Çalıştığım kurumda pandemi için gerekli önlemleri yeterli buluyorum", "Pandemi sürecinde çalışma ortamımı sağlıklı ve güvenilir olduğunu düşünüyorum", "Kurumumun yeterli düzeyde dezenfekte edildiğini düşünüyorum", "Kurumda çalışanların sosyal mesafe kurallarına uyduğunu düşünüyorum", "Çalışma arkadaşlarımın sağlık ve güvenlik konusunda gerekli önlemi aldığını düşünüyorum", "Çalıştığım kurumda COVID-19 ile ilgili gerekli bilgilendirmelerin yapıldığını düşünüyorum(afiş, bilgilendirme yazıları)", "Pandemi sürecinde kurumumdan bilgilendirme eğitimi aldım".

Faktör 2'de yer alan sorular şunlardır: "Her gün işe gelirken virüs bulaşma kaygısı duyuyorum", "Her iş çıkışında eve gittiğimde aileme virüs bulaştırmaktan korkuyorum", "Daireye 
gelen vatandaşların bizim için risk oluşturduğunu düşünüyorum", "Pandemi devam ettikçe normal çalışma düzenine yeniden dönmeyi uygun bulmuyorum", "Pandemi sürecinde sağlı̆̆ım yerinde olsa da işe geldiğimde sürekli COVID-19 belirtileri varmış gibi hissediyorum", "Kurumda uygun işlerin uzaktan çalışma şekline dönüştürülmesi gerektiğini düşünüyorum", "Pandemi sonrası kurumumuzda psikolojik destek programları uygulanmalı".

Faktör 3'te yer alan sorular şunlardır: "Pandemi süreci çalışma motivasyonumu oldukça kötü etkiledi", "Pandemi sürecinde çalışma performansım düştü", "Pandemi sürecinde özel hayatım ve iş hayatım arasındaki denge bozuldu", "Pandemi sürecinde uyku kalitem bozuldu", "İnternette/sosyal medyada yer alan haberleri sürekli takip ediyorum ve COVID-19 pandemisinin biteceğine dair düşüncelerimi sürekli olumsuz etkiliyor", "Çalışanlar içinde idari izinlilerin olması iş yükümü daha çok artırdı”.

Bu çalışmanın sonuçları ile faktörler "Pandemide Örgütsel Tutum", "Pandemide Bireysel Tutum", "Pandemide Çalışma Tutumu" olarak isimlendirilmiştir.

\section{Sonuç}

COVID-19 virüsü, etkilerini küresel çapta göstermesi nedeniyle Dünya Sağlık Örgütü tarafından pandemi olarak ilan edilmiştir. Bu virüsün görüldüğü ülkelerin sağlık sektörü yanında ekonomileri de olumsuz etkilenmiştir. COVID-19 virüsünün görüldüğ̈̈ her ülke kendi mücadele yöntemlerini belirleyerek bu süreçten en hafif şekilde etkilenmeyi amaçlamaktadır. Türkiye, henüz COVID-19 vakası görülmeden önce gerekli tedbir ve önlemleri almış, 11 Mart 2020 tarihli ilk vaka görülmesi ile birlikte alınan tedbir ve önlemleri aşamalı olarak daha da sıkılaştırmıştır. Bu tedbir ve önlemler çalışma hayatında da uygulamaya konulmuştur. Bu süreçte kamu personeli ile ilgili çalışma hayatına ilişkin düzenlemelerde önem arz etmektedir.

COVID-19 pandemi sürecinde konut satışlarında gerçekleşen azalmaya karşın Tapu ve Kadastro Genel Müdürlüğü’ne bağl1 çalışan personelin yaptığ iş̧lem sayısı azalsa da (Nisan-Mayıs aylarında) iş yükü fazlalığı devam etmiştir. 1 Haziran 2020 tarihli normalleşme dönemi ile COVID19 pandemi sürecinde alınan önlem ve tedbirlerin yeniden düzenlenmesi ve çalışma hayatının yeni normale dönmesi sağlanmıştır. COVID-19 pandemi süreci ve normalleşme döneminde kamu hizmetinin devamı için kamu personeli çalışmaya devam etmiştir. Ekonomik hayatı düzenlemek adına 1 Haziran 2020 tarihinde Hazine ve Maliye Bakanlığı'nın açıkladığı konut, taşıt, tatil ve sosyal hayatı destek kredi paketleri ile birlikte özellikle ipotekli konut satışlarındaki artışla Tapu Müdürlükleri'ne bağlı çalışan personelin iş yükü normalleşme döneminde daha da artış göstermiştir. $\mathrm{Bu}$ çalışmada, ipotekli konut satışlarındaki artış nedeniyle iş yükü daha da artan Tapu Müdürlükleri'ne bağlı çalışan personelin COVID-19 pandemi süreci ve normalleşme döneminde pandemi karşısındaki tutumlarının değerlendirilmesi amaçlanmıştır. Çalışma, Türkiye'de Tapu ve Kadastro Müdürlüğü'ne bağlı çalışan 2859 katılımcıyla gerçekleşmiştir.

Araştırma sonuçlarına göre; anket katılımcıları, kredi destek paketi içinde yer alan konut kredisine bağlı olarak iş yüklerinin daha da arttı̆̆ 1 ve konut alış ve satış1 için daireye gelen vatandaşların kendileri için risk oluşturduğunu ifade etmiştir. Bu durum, özellikle tapu personelinin psikolojisini negatif yönlü etkilemekte, çalışanın kurumundan beklentilerini azaltmaktadır. Tapu Müdürlüğü'ne bağlı çalışanların işlem sayısının artması bir çıktı olarak düşünüldüğünde normalleşme döneminde çalışan verimliliğinin de artması dikkat çekmektedir (TKGM, 2020 d). Bunun sonucunda Tapu ve Kadastro Genel Müdürlüğü'ne bağlı çalışan personelin COVID-19 pandemi süreci ve normalleşme döneminde yoğun bir çalışma içinde olduğu anlamına gelmektedir.

Araştırma sonucundan elde edilen verilere göre; daha önce 2 faktörden oluştuğu belirlenen "Kamu çalışanlarının pandemi karşısındaki tutum ölçeği" bu çalışma ile 3 faktöre evrilerek son halini almıştır. Ölçekte yer alan faktörler; "Pandemide Örgütsel Tutum", "Pandemide Bireysel Tutum", "Pandemide Çalışma Tutumu" olarak isimlendirilmiştir. Anket katılımcılarının sorulara verdiği 
cevaplar dikkate alındığında, Türkiye'de diğer kamu kurum ve kuruluşlarında çalışanlarının pandemi karşısındaki tutumlarının ve pandemi sürecinde beklentilerinin ne olduğu konusunun incelenmesi önemlidir. Çünkü pandeminin ortaya çıkardığı ekonomik, sosyal ve psikolojik etkiler çalışan birey açısından önem arz etmektedir. Pandemi sürecinin çalışan açısından daha sağlıklı ve verimli geçirilmesi, çalışan mutluluğunun sağlanması sadece çalışan için değil onların bakmakla sorumlu olduğu bireyler için de oldukça önemlidir. Bu nedenle pandemi süreci ve normalleşme döneminde pandeminin çalışanlar üzerinde bıraktığı etkilerin çok yönlü değerlendirilmesi ve bunun için ilgili kurumlarca gerekli psikolojik desteğin sağlanması önem arz etmektedir.

\section{Kaynakça}

Aslan, R. (2020). Tarihten günümüze epidemiler, pandemiler ve covid-19. Göller Bölgesi Aylık Ekonomi ve Kültür Dergisi, 8 (85), 35-41.

Balc1, Y., Çetin G. (2020). Covid-19 pandemi sürecinin Türkiye'de istihdama etkileri ve kamu açısından alınması gereken tedbirler. İstanbul Ticaret Üniversitesi Sosyal Bilimler Dergisi Covid-19 Sosyal Bilimler Özel Saylsl, 19 (37) Bahar (Özel Ek), 40-58.

Budak, F., Korkmaz Ş. (2020). Covid-19 pandemi sürecine yönelik genel bir değerlendirme: Türkiye örneği. Sosyal Araştırmalar ve Yönetim Dergisi, (1), 62-79. https://doi.org/10.35375/sayod.738657

Gümüş, H., Özgül, S.A. (2017). Rekreasyon alanı kullanımına ilişkin katılım engelleri ve tercih etkenleri ölçeklerinin geliştirilmesi. Journal of Human Sciences, 14 (1), 865-882. https://doi:10.14687/jhs.v14i1.4448

Halkbank, Konut Kredi Paketi, https://www.halkbank.com.tr/21977destek_urunleri_kredi_paketleri (Erişim Tarihi: 03.06.2020).

Hamouche, S. (2020). COVID-19 and employees' mental health: stressors, moderators and agenda for organizational actions. Emerald Open Research, 2 (15), 1-11. doi:10.14687/jhs.v14i1.4448

Kara, E. (2020). COVID-19 pandemisi: işgücü üzerindeki etkileri ve istihdam tedbirleri, ASEAD, 7 (5), 269-282.

Karataş, Z. (2020). COVID-19 Pandemisinin toplumsal etkileri, değişim ve güçlenme. Türkiye Sosyal Hizmet Araştırmaları Dergisi, 4 (1), 3-15.

Kaya, M.F. (2013). Sürdürülebilir kalkınmaya yönelik tutum ölçeği geliştirme çalışması. Marmara Coğrafya Dergisi, 28, 175-193.

OECD, Global Economy Faces Gravest Threat Since The Crisis As Coronavirus Spreads, http://www.oecd.org/newsroom/global-economy-faces-gravest-threat-since-the-crisis-ascoronavirus-spreads.htm (Erişim Tarihi: 20.06.2020).

Özkoçak, V., Koç, F., Gültekin, T. (2020). Pandemilere antropolojik bakış: Koronavirüs (Covid-19) $\begin{array}{lllll}\text { örneği. } & \text { Turkish } & \text { Studies, } & 15 & \text { (2), }\end{array}$ https://dx.doi.org/10.29228/TurkishStudies.42679

Resmi Gazete (Sayı: 31067), Kamu Görevlilerinin Yurt Dışına Çıkış İzni Hakkında Genelge, https://www.resmigazete.gov.tr/eskiler/2020/03/20200313.pdf (Erişim Tarihi: 31.06.2020).

Resmi Gazete (Sayı: 31074), Organizasyonların Ertelenmesi Hakkında Genelge, https://www.resmigazete.gov.tr/eskiler/2020/03/20200320.pdf (Erişim Tarihi: 30.06.2020). 
Resmi Gazete (Sayı: 31076 (Mükerrer), COVID-19 Kapsamında Kamu Çalışanlarına Yönelik İlave Tedbirler Hakkinda Genelge, https://www.resmigazete.gov.tr/eskiler/2020/03/20200322M1-1.pdf (Erişim Tarihi: 31.06.2020).

Resmi Gazete (Sayı: 31139 Mükerrer), COVID-19 Kapsamında Kamu Kurum ve Kuruluşlarında Normalleşme ve Alınacak Tedbirler Hakkında Genelge, https://www.resmigazete.gov.tr/eskiler/2020/05/20200529M1.pdf (Erişim Tarihi: 31.06.2020).

Sağlık Bakanlığı (2020a), Korona Web Sitesi, http://koronaonlem.saglik.gov.tr (Erişim Tarihi: 21.06.2020).

Sağlık Bakanlığı (2020b), Kurum ve İşletmelere Yönelik Enfeksiyon Kontrol Önlemleri, https://covid19bilgi.saglik.gov.tr/tr/alinan-karalar.html (Erişim Tarihi:13.07.2020).

Soylu Bayram, Ö. (2020). Türkiye ekonomisinde covid-19'un sektörel etkileri. ASEAD, 7 (5),169185.

T.C. Cumhurbaşkanlığı, Normal Hayata Dönüşü Kademe Kademe Başlatacağız, https://www.tccb.gov.tr/haberler/410/119206/-normal-hayata-donusu-kademe-kademebaslatacagiz- (Erişim Tarihi: 13.06.2020).

T.C. Hazine ve Maliye Bakanlığı, Kredi Destek Paketleri, https://www.hmb.gov.tr/kategori/basinduyurulari (Erişim Tarihi: 25.06.2020).

T.C. İçişleri Bakanlığı $\left(2020_{\mathrm{a}}\right)$, Umuma Açık İstirahat ve Eğlence Yerleri Hakkında Genelge, https://www.icisleri.gov.tr/81-il-valiligine-coronavirus-tedbirleri-konulu-ek-genelgegonderdi (Erişim Tarihi: 31.07.2020).

T.C. İçişleri Bakanlığı (2020b), Umuma Açık İstirahat ve Eğlence Yerleri Hakkında Ek Genelge, https://www.icisleri.gov.tr/81-il-valiligine-coronavirus-tedbirleri-konulu-ek-genelgegonderdi (Erişim Tarihi: 31.07.2020).

T.C. İçişleri Bakanlığı (2020c), Berber, Kuaför, Güzellik Merkezlerinin Faaliyetleri Hakkında Ek Genelge, https://www.icisleri.gov.tr/bakanligimiz-81-il-valiligine-koronavirus-tedbirlerikonulu-ek-bir-genelge-daha-gonderdi (Erişim Tarihi: 15.07.2020).

T.C. İçişleri Bakanlığı $\left(2020_{\mathrm{d}}\right)$, Ticari Taksilerle İlgili Yeni Bir Genelge, https://www.icisleri.gov.tr/81-il-valiligine-koronavirus-tedbirleri-kapsaminda-ticaritaksilerle-ilgili-genelge (Erişim Tarihi: 16.07.2020).

T.C. İçişleri Bakanlığı $\left(2020_{\mathrm{e}}\right)$, Semt ve Mahalle Pazarlarına S1k1 Denetim, https://www.icisleri.gov.tr/81-lde-semt-ve-mahalle-pazarlarina-siki-denetim (Erişim Tarihi: 21.06.2020).

T.C. İçişleri Bakanlığı $\left(2020_{\mathrm{f}}\right)$, Esnek Çalışma Yazısı Yayımladı, https://www.mevzuatinyeri.com/genel/icisleri-bakanligi-esnek-calisma-yazisi-yayimladih27411.html (Erişim Tarihi: 29.06.2020).

T.C. Milli Eğitim Bakanlığı, Koronavirüs'e Karşı Eğitim Alanında Alınan Tedbirler, https://www.meb.gov.tr/bakan-selcuk-koronaviruse-karsi-egitim-alaninda-alinan-tedbirleriacikladi/haber/20497/tr (Erişim Tarihi: 18.07.2020)

TKGM (2014), Satış - İpotek İşlemi, https://www.tkgm.gov.tr/sites/default/files/satis_ipotek_0.pdf (Erişim Tarihi: 15.07.2020). 
TKGM (2020a), Tarihçe, https://www.tkgm.gov.tr/tr/sayfa/tarihce-gorevler (Erişim Tarihi: 31.05.2020).

TKGM (2020b), Teşkilat Şeması, https://www.tkgm.gov.tr/tr/sayfa/teskilat-semasi (Erişim Tarihi: 31.05.2020).

TKGM $\left(2020_{\mathrm{c}}\right)$, Koronavirüs ile Etkin Mücadelede Alınan Kararlar, https://www.tkgm.gov.tr/tr/icerik/genel-mudurlugumuzun-covid-19-corona-virusu-ileetkin-mucadele-cercevesinde-aldigi-kararlara (Erişim Tarihi: 31.05 .2020 ).

TKGM $\left(2020_{\mathrm{d}}\right)$, Türkiye Geneli Toplam İşlem Değer ve Harç Miktarları, http://uygulamalar.tkgm.gov.tr/ybs/ybs/Tapuistatistik_Arsiv/2019/Aralik/TapuIstatistik.20 19.htm (Erişim Tarihi: 31.05.2020).

TÜIK, Konut Satış İstatistikleri, https://biruni.tuik.gov.tr/medas/?kn=73\&locale=tr (Erişim Tarihi: 30.07.2020).

Üstün, Ç., Özçiftçi, S. (2020). COVID-19 pandemisinin sosyal yaşam ve etik düzlem üzerine etkileri: bir değerlendirme çalışması. Anadolu Kliniği Tıp Bilimleri Dergisi, 25 (Özel Sayı 1), 142153. https://doi.org/10.21673/anadoluklin.721864

Vakıfbank, Konut Kredi Paketi, https://www.vakifbank.com.tr/Default.aspx?pageID=3909 (Erişim Tarihi: 03.06.2020).

WHO, Q\&A on Coronaviruses (COVID-19), https://www.who.int/emergencies/diseases/novelcoronavirus-2019/question-and-answers-hub/q-a-detail/q-a-coronaviruses (Erişim Tarihi: 08.07.2020).

Yaşlığlu, M.M. (2017). Sosyal bilimlerde faktör analizi ve geçerlilik: keşfedici ve doğrulayıcı faktör analizlerinin kullanılması. İstanbul Üniversitesi Işsletme Fakültesi Dergisi, 46, (Özel Sayı), 74-85.

Yelboğa, N., Aslan, Ş.B. (2020). Sosyal sorun olarak salgın hastalıklar ve sosyal çalışmanın halk sağlığını koruma/geliştirme görevi. Türkiye Sosyal Hizmet Araştırmaları Dergisi, 4 (1), 43 49.

Yılmaz, B. (2020). COVID-19 pandemi sürecinin çalışanlar üzerine etkisi: kamu sektöründe çalışanlar üzerine uygulamalı bir araştırma. Üçüncü Sektör Sosyal Ekonomi Dergisi, 55 (3), 1724-1740, https://doi: 10.15659/3.sektor-sosyal-ekonomi.20.08.1422

YÖK, Koronavirüs (Covid-19) Bilgilendirme Notu:1, https://covid19.yok.gov.tr/Documents/alinankararlar/02-coronavirus-bilgilendirme-notu-1.pdf (Erişim Tarihi: 12.07.2020).

Yükseler, Z. (2020). "Koronavirüs (COVID-19) salgınının istihdam ve büyümeye etkisi. https://www.researchgate.net/publication/340511319_KORONAVIRUS_COVID19_SALGINININ_ISTIHDAM_VE_BUYUMEYE_ETKISI (Erişim Tarihi: 13.06.2020).

Zeybekoğlu Akbaş, Ö., Dursun, C. (2020), Koronavirüs (COVID-19) pandemisi sürecinde özel alanına kamusal alanı sığdıran çalışan anneler. ASEAD, 7 (5), 78-94.

Ziraat Bankas1, Konut Kredi Paketi, https://www.ziraatbank.com.tr/tr/kampanyalar/yeni-kredipaketleri (Erişim Tarihi: 03.06.2020). 